\title{
Fish assemblages in seagrass habitat along the Jordanian coast of the Gulf of Aqaba
}

\author{
Maroof A. Khalaf $^{1^{*}}$, Saber Al-Rousan ${ }^{2}$, Fuad A. Al-Horani ${ }^{1}$ \\ ${ }^{1}$ Department of Marine Biology, Faculty of Marine Sciences, The University of Jordan-Aqaba, Aqaba, Jordan; \\ *Corresponding Author: m.khalaf@ju.edu.jo \\ ${ }^{2}$ Marine Science Station, The University of Jordan, Aqaba, Jordan
}

Received 27 May 2012; revised 30 June 2012; accepted 10 July 2012

\begin{abstract}
The spatial distribution and community structure of the fishes were studied at different depths and sites along the Jordanian coast in seagrass habitat. A total of 37,034 fishes were counted representing 132 species belonging to 35 families observed during visual census in three sites (average of $\mathbf{4 7 4 1 . 6}$ fish per transect). Out of the 132 species encountered, 5 species of them including Neopomacentrus miryae Lethrinus borbonicus, Pseudanthias squamipinnis, Lethrinus variegatus, Siganus rivulatus accounted for $\mathbf{5 7 . 7 \%}$ of all individuals. Fishes were most abundant and significantly higher at $12 \mathrm{~m}$ depths (mean $\mathrm{N}=2889.6$ ) in comparison with shallow $6 \mathrm{~m}$ depth (mean $=1225.3$ with $(p=$ 0.0218). This may be attributed to many planktivorous fishes that inhabit this depth such as $P$. squampinnis, Paracheilinus octotaenia, Chromis pelloura, Decapterus macarellus, and Cirrhilabrus rubriventralis probably with high abundance of plankton at $12 \mathrm{~m}$ depth than $6 \mathrm{~m}$. The number of species was significantly higher in Phosphate Loading Berth (PLB; mean $S=54.7$ ) than in Hotels area site $(H A$; mean $S=12.8)$ with $(p=0.0002)$ and Tala Bay site (TB; mean $S=31$ ) with $(p=0.0484)$. This may be due to higher hard coral cover at Phophate Loading Berth.
\end{abstract}

Keywords: Fish Assemblages; Seagrass Habitat; Gulf of Aqaba; Red Sea

\section{INTRODUCTION}

Seagrass beds are presumed to have a fundamental role in maintaining fish populations by providing one or more of the followings: a permanent habitat, allowing completion of the full life cycle, a temporary nursery area for the successful development of the juvenile stages, a feeding area for various life stages and/or a refuge from predation $[1,2]$. The seagrass beds in the Red Sea are found from mid-tidal level, on shores receiving regular tides, to about $70 \mathrm{~m}$ depth [3]. They tend to be concentrated in shallow water areas such as lagoons, sharms (drowned wadi mouths), and mersas (shallow embayments) because of the soft-bottom sediments found in these areas [4]. The seagrass, Halophila stipulacea has been described as generally having a wide ecological range, growing from intertidal to depths of greater than $50-70 \mathrm{~m}$ [5-8]. Eleven species of all the seven known genera of seagrass have been reported in the Red Sea [4]. Out of the six species reported in the Gulf of Aqaba, only Halophila stipulacea, Halophila ovalis and Halodule uninervis were found at the extreme northern end of the Gulf of Aqaba [9,10]. They serve as important nursery grounds for fish larvae and hosts sea urchins and sea cucumbers [11]. In general, the community is structurally and functionally complex.

The Red Sea Ichtyofauna is quite well known compared to other parts of the tropical Indo-Pacific Ocean. About 507 fish species have been recorded in the Gulf of Aqaba [12]. The number of fish species recorded in the Red Sea is about 1300 [13]. [14] reported Novaculichthys macrolepidotus as a new record from the Gulf of Aqaba inhabiting a seagrass Halodule uninervis at $2 \mathrm{~m}$ depth.

During the last four decades, the coral reefs of Aqaba and Eilat undergone major changes resulting from increasing impacts due to human activities $[15,16]$. Rapid developments in Aqaba city during the past few years have identified the pressure on coral reefs and seagrass habitat including phosphate loading berth, toursistic projects, ports relocation and other anthropogenic activities.

The objective of this study was to carry out a thorough fish survey at various sections of the Jordanian Gulf of Aqaba within an area distinguished for its seagrass. The 
main aim of this study was to describe the fish community structure in the area.

\section{MATERIAL AND METHODS}

\subsection{Site Description}

The Gulf of Aqaba (180 km long, $20 \mathrm{~km}$ wide) is a semi-closed sea with many unique natural and physical features. It is geographically isolated by the narrow Strait of Tiran. While much of the Gulf is deep ( $>1800 \mathrm{~m})$, the northern sector has a relatively shallow shelf adjacent to the major population centers. The Jordanian coast $(27 \mathrm{~km})$ is fringed by discontinuous belt of reefs separated by sandy bottoms that are usually covered by seagrass meadows [17]. Three sites distributed along the Jordanian coast (Figure 1) presenting seagrass meadows. The Gulf is characterized by calm and clear water with diurnal tides in the range of less than one meter. Currents specifically, and circulation generally, appear to be largely wind-driven, with additional influence from tides, density gradients, and evaporation $[18,19]$.

\subsection{Visual Census}

All fish surveys were conducted by visual census technique with SCUBA following the basic protocol outlined by [20]. In each site, three replicates of $50 \mathrm{~m}$ long marked transect lines, were deployed parallel to the sea shore at two different depths; one shallow $(6 \mathrm{~m})$ and one deep $(12 \mathrm{~m})$. The replicates were laid sequentially with a $10-20 \mathrm{~m}$ distance separating them. In all cases, the observer waited about $10 \mathrm{~min}$ before counting to allow the fish to resume their normal behaviour. Subsequently, the

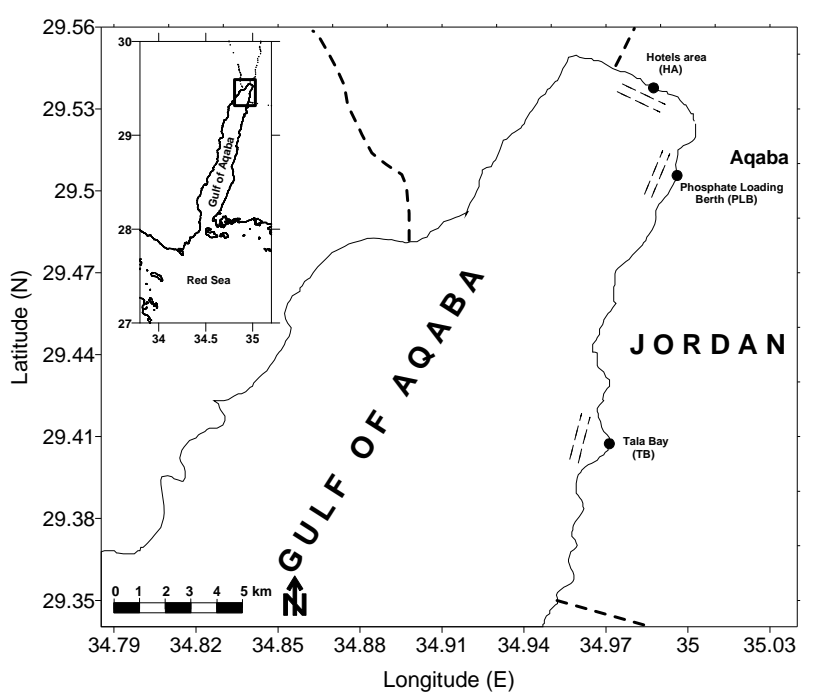

Figure 1. Location map of the northern tip of the Gulf of Aqaba showing fish survey transects at the three sampling sites as follows: $\mathrm{HA}=$ Hotels Area, $\mathrm{PLB}=$ Phosphate Loading Berth, $\mathrm{TB}=$ Tala Bay. observer swam along the transect and recorded all fishes encountered within $2.5 \mathrm{~m}$ on each side of the line and 5 $\mathrm{m}$ above transect. The duration for the fish count on each transect was approximately $40-50 \mathrm{~min}$. The surveys of benthic habitat at each visual census were conducted in by the line-point intercept method [21,22]. Three sea grass meadows sites distributed along the Jordanian coast (Figure 1) and have various types of benthic habitat were studied (Table 1).

\subsection{Statistical Analysis}

All statistical analyses used to examine the data were as described by [23] and implemented via StatView computer software. Fish abundance was described by relative abundance (RA) and frequency of appearance (FA), calculated as follows:

$$
\mathrm{RA}=\frac{\mathrm{Xi}}{\mathrm{Ya}} \times 100
$$

where, $\mathrm{Xi}$ is the pooled average abundance of species $\mathrm{i}$ from each depth and site, and Ya is the pooled average abundance of all species from each depth and site

$$
\mathrm{FA}=\frac{\mathrm{Ni}}{\mathrm{Nt}} \times 100
$$

where $\mathrm{Ni}$ is the number of transects in which species $\mathrm{i}$ was present and $\mathrm{Nt}$ is the total number of all transects. Species diversity $\left(\mathrm{H}^{\prime}\right)$ was calculated from the ShannonWeaver Diversity Index [24]:

$$
\mathrm{H}^{\prime}=-\sum(\text { pi ln pi })
$$

where $\mathrm{pi}$ is the proportion of all individuals counted that were of species i. Species richness (d) was calculated using Margslef's index [25] as follows:

$$
\mathrm{d}=\frac{(\mathrm{S}-1)}{\log (\mathrm{N})}
$$

where $\mathrm{S}$ is the total number of species, $\mathrm{N}$ is the total number of individuals

\section{RESULTS}

\subsection{Abundance and Frequency of Appearance}

A total of 37,034 fishes were counted in the present study representing 132 species that belong to 35 families with an average of 4741.6 fish per transect. The percent number of species per family showed the following rank: Labridae (19.70\%), Pomacentridae (8.33\%), Gobiidae $(6.06 \%)$ and Scorpaenidae, Apogonidae, Chaetodontidae, Blenniidae and Tetraodontidae (4.55\%, each). These eight families account for $56.82 \%$ of the total species. In terms of relative abundance per family the ichthyofauna 
Table 1. Listing of study sites and abbreviations with live substrate coverage $(\mathrm{HC}=$ hard coral, $\mathrm{SC}=$ soft coral, $\mathrm{DC}$ and $\mathrm{R}=\mathrm{dead}$ coral and rock, $\mathrm{S}=$ sand, $\mathrm{SG}=$ sea grass, others = other items which are not listed).

\begin{tabular}{ccccccc}
\hline Site & HC & SC & DC and R & S & SG & Others \\
\hline Hotels Area (HA) & 1.2 & 0.4 & 2.3 & 24.6 & 71.1 & 0.4 \\
Phosphate Loading Berth (PLB) & 5.8 & 0.7 & 4.5 & 52.5 & 35.7 & 0.8 \\
Tala Bay (TB) & 3.2 & 3.1 & 7.6 & 15.1 & 69.8 & 1.2 \\
\hline
\end{tabular}

showed the following rank: Lethrinidae (30.5\%), Pomacentridae (28.7\%), Serranidae (15.4\%), Siganidae (6.8\%), Labridae (5.0\%), Nemepteridae $(2.9 \%)$ and Carangidae $(2.6 \%)$. These 7 families account for $90.0 \%$ of the total population.

The most abundant species (Table 2) were Neopomacentrus miryae (23.7\%), Lethrinus borbonicus (22.7\%), Pseudanthias squamipinnis (15.3), Lethrinus variegatus (7.8\%), Siganus rivulatus $(6.2 \%)$, Scolopsis ghanam (2.9\%), Decapterus macarellus (2.6\%), Cirrhilabrus rubriventralis $(2.5 \%)$. These eight species made up $83.8 \%$ of the total population. Frequency of appearance (Table 2) suggest that the most common species were Dascyllus trimaculatus (72.2\%), P. squamipinnis, Parupeneus forsskali and Pomacentrus trichorous (60\%, each), Coris caudimaculata and Pteragogus pelycus (55.6\%, each).

Number of species ranged from eight species per transect in HA in transect No. 3 to 61 species in transect No. 3 in PLB with an average of 29.8 species per transect (Table 2). The number of fish individuals ranged from 83 to 5087 individuals at HA in transect No. 3 at $12 \mathrm{~m}$ with an average of 2057.4 fish per transect (Table 2). The average species richness ranged from 1.17 at St. 3 in $\mathrm{HA}$ at $12 \mathrm{~m}$ to 7.23 in PLB at $12 \mathrm{~m}$ with an average of 3.9 (Table 2). Shannon-Wiener diversity index ranged from 0.5 at St. 3; in BB at $6 \mathrm{ml}$ to 2.76 in PLB with an average of 1.4 (Table 2).

\subsection{Site Fish Distribution}

At the HA the results indicated that the most abundant species were L. borbonicus (54.9\%), L. variegatus (18.67\%), S. ghanam $(6.9 \%)$, D. macarelus $(6.2 \%)$, and rivulated rabbitfish $S$. rivulatus $(3.6 \%)$, and $C$. rubriventralis $(3.4 \%)$. These five species made up $90.3 \%$ of the total population within North Beach site.

N. miryae, was the most abundant species at the PLB, representing $(71.3 \%)$ of the total fish population followed by $P$. squamipinnis $(4.4 \%)$, P. trichourus $(3.5 \%)$, Chromis pelloura (3.1\%), the coral reef species P. octotaenia $(2.5 \%)$. These five species made up $84.8 \%$ of the total fish population.

At the TB, the most abundant fish species were $P$. squamipinnis $(54.6 \%)$, S. rivulatus $(18.6 \%)$, C. rubriven- tralis (4.4\%), C. pelloura (3.1\%), and Sargocentron diadema $2.9 \%$. These five species made up $82.8 \%$ of the total population.

The number of species (S) was significantly higher in PLB (mean $S=45.7$ ) than in HA site (mean $S=12.8$ ) with $(\mathrm{p}=0.0002)$ and $\mathrm{TB}$ site (mean $\mathrm{S}=31.0)$ with $(\mathrm{p}=$ 0.0484 ). Also, the species richness was significantly higher in PLB (mean $d=6.1$ ) than in HA site (mean $d=$ 1.6) with $(\mathrm{p} \leq 0.0001)$ and TB site (mean $\mathrm{d}=4.1)$ with $(\mathrm{p}=0.0251)$. Whereas, number of individuals and Shannon-Wiener diversity Index did not show any significant differences between the three sites (Figure 2, Table 3).

\subsection{Depth Fish Distribution}

The most abundant fish species at $6 \mathrm{~m}$ deep transects were $N$. miryae $(38.1 \%)$, followed by $P$. squamipinnis (23.5\%), L. borbonicus (9.2\%), S. ghanam (4.9\%), Cheilodipterus novemstriatus (3.1\%), L. variegatus, and P. trichorous $(2.7 \%$, each). These 7 species made up $84.2 \%$ of the total fish population. Whereas, the most abundant species at $12 \mathrm{~m}$ deep transects were $L$. borbonicus $(28.5 \%)$, followed by $N$. miryae $(17.6 \%), P$. squamipinnis $(11.9 \%)$, L. variegatus $(10.0 \%)$, Siganus rivulatus $(8.8 \%)$, D. macarellus $(3.7 \%)$, and C. rubriventralis $(3.6 \%)$. These 7 species made up $84.1 \%$ of the total fish population.

The number of individuals (N) was significantly higher in $12 \mathrm{~m}$ deep transects (mean $\mathrm{N}=2889.6$ ) than in 6 m deep transects (mean $\mathrm{N}=1225.3)$ with $(\mathrm{p}=0.0218)$. Whereas number of species, species richness and Shannon-Weiner Diverssity Index did not show any significant difference (Figure 3, Table 3).

\section{DISCUSSION}

A comprehensive description of the fish community structure in the seagrass benthic habitats in the Jordanian coast of the Gulf of Aqaba is presented in this study. A comparison of differences between the fish assemblages in relation to depth was also made. Out of 507 species of fish present in the Jordanian coast [12], this study indicate the presence of 132 fish species $(26 \%)$ inhabiting shallow water in 3 sites only.

The Hotels Area (HA) site is dominated by economi- 
Table 2. Frequency of apperance (FA) and Relative abundance (RA) values for each fish species at the three sites along the Jordanian coast of the Gulf of Aqaba.

\begin{tabular}{|c|c|c|c|c|c|}
\hline Fish species & FA & $\mathbf{R A}$ & Fish species & FA & RA \\
\hline Gymnothorax griseus & 27.78 & 0.02 & Teixeirichthys jordani & 27.78 & 0.04 \\
\hline Gymnothorax sp.1 & 11.11 & 0.01 & Anampses lineatus & 11.11 & 0.02 \\
\hline Pisiodonophis cancrivorus & 5.56 & 0.00 & Anampses twistii & 16.67 & 0.01 \\
\hline Saurida gracilis & 16.67 & 0.01 & Bodianus anthioides & 11.11 & 0.01 \\
\hline Synodus variegatus & 44.44 & 0.08 & Cheilinus trilobatus & 27.78 & 0.05 \\
\hline Trachinocephalus myops & 5.56 & 0.00 & Cheilinus diagrammus & 11.11 & 0.02 \\
\hline Myripristis murdjan & 5.56 & 0.00 & Cheilinus mentalis & 50.00 & 0.14 \\
\hline Neoniphon sammara & 5.56 & 0.01 & Cheilio inermis & 11.11 & 0.01 \\
\hline Sargocentron diadema & 33.33 & 0.77 & Coris caudimacula & 61.11 & 0.38 \\
\hline Fistularia commersonii & 5.56 & 0.01 & Coris variegata & 11.11 & 0.01 \\
\hline Aeoliscus punctulatus & 11.11 & 0.03 & Cirrhilabrus rubriventralis & 38.89 & 2.52 \\
\hline Corythoichthys flavofasciatus & 5.56 & 0.00 & Gomphosus caeruleus & 16.67 & 0.05 \\
\hline Corythoichthys schultzi & 38.89 & 0.10 & Hemigymnus fasciatus & 5.56 & 0.00 \\
\hline Trachyrhamphus bicoarctatus & 16.67 & 0.02 & Hologymnosus annulatus & 5.56 & 0.01 \\
\hline Dendrochirus brachypterus & 22.22 & 0.03 & Labroides dimidiatus & 55.56 & 0.06 \\
\hline Inimicus filamentosus & 22.22 & 0.02 & Larabicus quadrilineatus & 27.78 & 0.02 \\
\hline Pterois miles & 38.89 & 0.10 & Macropharyngodon bipartitus & 11.11 & 0.01 \\
\hline Pterois radiata & 22.22 & 0.02 & Oxycheilinus orientalis & 27.78 & 0.16 \\
\hline Scorpionopsis sp. & 11.11 & 0.02 & Pseudocheilinus evanidus & 16.67 & 0.03 \\
\hline Cephalopholis hemistiktos & 11.11 & 0.01 & Pseudocheilinus hexataenia & 16.67 & 0.01 \\
\hline Epinephelus fasciatus & 22.22 & 0.02 & Pteragogus cryptus & 5.56 & 0.00 \\
\hline Variola louti & 11.11 & 0.01 & Pteragogus pelycus & 61.11 & 0.25 \\
\hline Pseudanthias squamipinnis & 66.67 & 15.33 & Stethojulis albovittata & 5.56 & 0.01 \\
\hline Pseudanthias taeniatus & 11.11 & 0.01 & Thalassoma rueppellii & 22.22 & 0.05 \\
\hline Pseudochromis fridmani & 22.22 & 0.06 & Thalassoma lunare & 27.78 & 0.06 \\
\hline Pseudochromis olivaceus & 16.67 & 0.01 & Xyrichtys pentadactylus & 5.56 & 0.00 \\
\hline Pseudochromis pesi & 5.56 & 0.01 & Calotomus viridescens & 33.33 & 0.08 \\
\hline Pseudochromis springeri & 22.22 & 0.03 & Leptoscarus vaigiensis & 33.33 & 0.34 \\
\hline Apogon aureus & 5.56 & 0.01 & Scarus ghobban & 5.56 & 0.01 \\
\hline Apogon cyanosoma & 55.56 & 0.31 & Chlorurus gibbus & 5.56 & 0.01 \\
\hline Apogon exostigma & 11.11 & 0.01 & Scarus psittacus & 16.67 & 0.13 \\
\hline Cheilodipterus lachneri & 16.67 & 0.03 & Parapercis hexophtalma & 27.78 & 0.02 \\
\hline Cheilodipterus macrodon & 16.67 & 0.03 & Aspidontus taeniatus & 5.56 & 0.01 \\
\hline Cheilodipterus novemstriatus & 50.00 & 1.27 & Ecsenius aroni & 5.56 & 0.01 \\
\hline Decapterus macarellus & 11.11 & 2.57 & Ecsenius frontalis & 11.11 & 0.02 \\
\hline
\end{tabular}




\begin{tabular}{|c|c|c|c|c|c|}
\hline Caesio suevica & 5.56 & 0.12 & Ecsenius gravieri & 11.11 & 0.01 \\
\hline Scolopsis ghanam & 61.11 & 2.92 & Meiacanthus nigrolineatus & 44.44 & 0.24 \\
\hline Gerres oyena & 27.78 & 1.07 & Plagiotremus rhinorhynchos & 5.56 & 0.00 \\
\hline Diagramma pictum & 5.56 & 0.01 & Amblyeleotris steinitzi & 5.56 & 0.01 \\
\hline Lethrinus borbonicus & 33.33 & 22.72 & Amblygobius albimaculatus & 50.00 & 0.07 \\
\hline Lethrinus variegatus & 27.78 & 7.81 & Asterropteryx semipunctatus & 22.22 & 0.02 \\
\hline Lethrinus sp. & 5.56 & 0.01 & Bryaninops natans & 5.56 & 0.08 \\
\hline Mulloidichthys flavolineatus & 11.11 & 0.06 & Gnatholepis anjerensis & 33.33 & 0.17 \\
\hline Parupeneuscy clostomus & 11.11 & 0.01 & Gobiodon citrinus & 5.56 & 0.02 \\
\hline Parupeneus forsskali & 66.67 & 0.27 & Istigobius decoratus & 16.67 & 0.04 \\
\hline Parupeneus macronema & 50.00 & 0.72 & Vanderhorstia sp. & 5.56 & 0.00 \\
\hline Upeneus tragula & 27.78 & 0.42 & Acanthurus nigrofuscus & 38.89 & 0.11 \\
\hline Chaetodon auriga & 5.56 & 0.00 & Ctenochaetus striatus & 27.78 & 0.04 \\
\hline Chaetodon austriacus & 22.22 & 0.03 & Zebrasoma veliferum & 5.56 & 0.01 \\
\hline Chaetodon fasciatus & 5.56 & 0.01 & Zebrasoma xanthurum & 5.56 & 0.01 \\
\hline Chaetodon paucifasciatus & 38.89 & 0.06 & Siganus luridus & 27.78 & 0.59 \\
\hline Heniochus diphreutes & 22.22 & 0.05 & Siganus rivulatus & 16.67 & 6.21 \\
\hline Heniochus intermedius & 22.22 & 0.03 & Bothus pantherinus & 16.67 & 0.01 \\
\hline Apolemichthys xanthotis & 11.11 & 0.01 & Pardachirus marmoratus & 5.56 & 0.00 \\
\hline Centropyge multispinis & 11.11 & 0.01 & Sufflamen albicaudatum & 38.89 & 0.05 \\
\hline Amblyglyphidodon flavilatus & 5.56 & 0.03 & Paramonacanthus pusillus & 22.22 & 0.02 \\
\hline Amphiprion bicinctus & 50.00 & 0.11 & Pervagor randalli & 11.11 & 0.01 \\
\hline Chromis dimidiata & 38.89 & 0.12 & Ostracion cubicus & 27.78 & 0.02 \\
\hline Chromis pelloura & 27.78 & 1.84 & Arothron hispidus & 22.22 & 0.02 \\
\hline Chromis ternatensis & 16.67 & 0.12 & Arothron stellatus & 5.56 & 0.00 \\
\hline Chromis weberi & 16.67 & 0.04 & Canthigaster coronata & 55.56 & 0.09 \\
\hline Dascyllus marginatus & 50.00 & 0.74 & Canthigaster margaritata & 50.00 & 0.11 \\
\hline Dascyllus trimaculatus & 72.22 & 0.51 & Canthigaster pygmaea & 5.56 & 0.00 \\
\hline Neopomacentrus miryae & 33.33 & 23.68 & Torquigener flavimaculosus & 33.33 & 0.38 \\
\hline Pomacentrus trichourus & 66.67 & 1.50 & Cyclichthys spilostylus & 27.78 & 0.02 \\
\hline
\end{tabular}

Table 3. P-values of number of species (S), number of individuals $(\mathrm{N})$, species richness $(\mathrm{d})$ and Shannon-Wiener diversity $\left(\mathrm{H}^{\prime}\right)$ between two depths 6 and $12 \mathrm{~m}$ and between sites (TB = Tala Bay, HA = Hotels Area, PLB = Phosphate Loading Berth).

\begin{tabular}{ccccc}
\hline & $6 \mathrm{~m}$ vs $12 \mathrm{~m}$ & HA vs PLB & TB vs PLB & TB vs HA \\
\hline S & 0.1159 & $\mathbf{0 . 0 0 0 2}$ & $\mathbf{0 . 0 4 8 4}$ & $\mathbf{0 . 0 1 7 8}$ \\
$\mathrm{N}$ & $\mathbf{0 . 0 2 1 8}$ & 0.6029 & 0.6207 & 0.3163 \\
$\mathrm{D}$ & 0.1908 & $<\mathbf{0 . 0 0 0 1}$ & $\mathbf{0 . 0 2 5 1}$ & $\mathbf{0 . 0 1 0 2}$ \\
H' & 0.3540 & 0.3229 & 0.3013 & 0.9620 \\
\hline
\end{tabular}



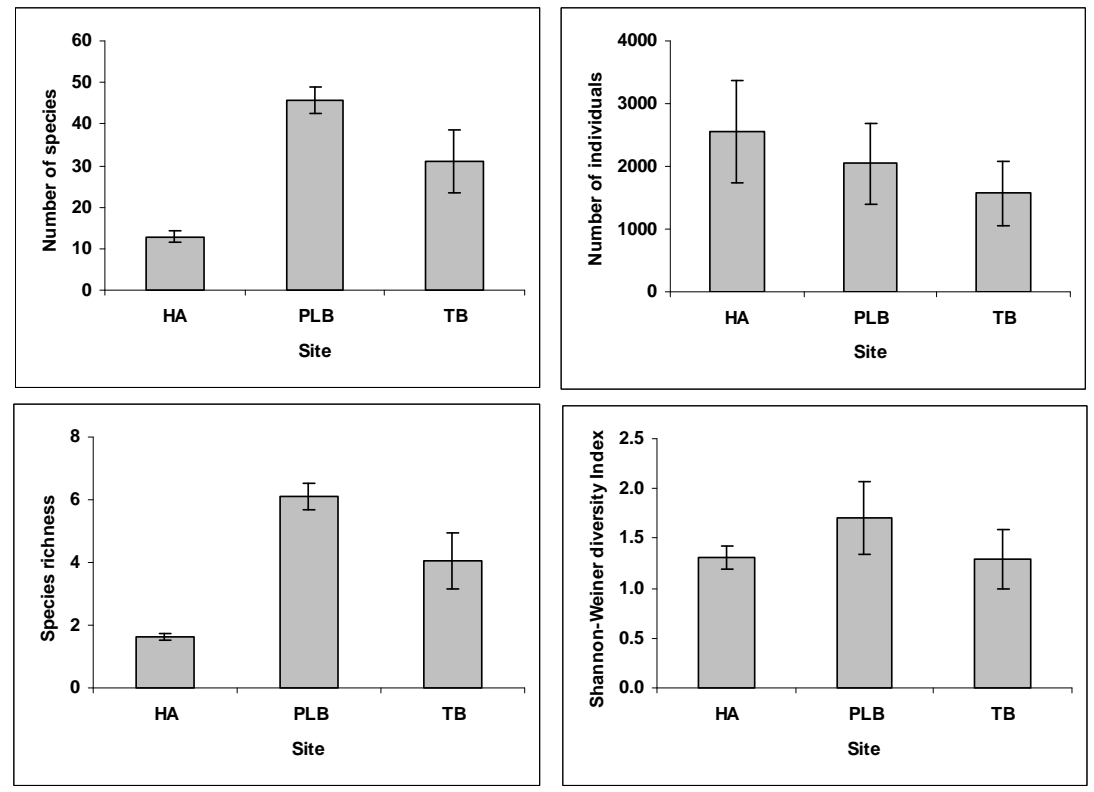

Figure 2. Average number of species, average number of individuals, average species richness and Average Shannon Wiener Diversity Index at the studies sea grass sites $\mathrm{HA}=$ Hotels Area, PLB $=$ Phosphate Loading Berth and TB $=$ Tala Bay.
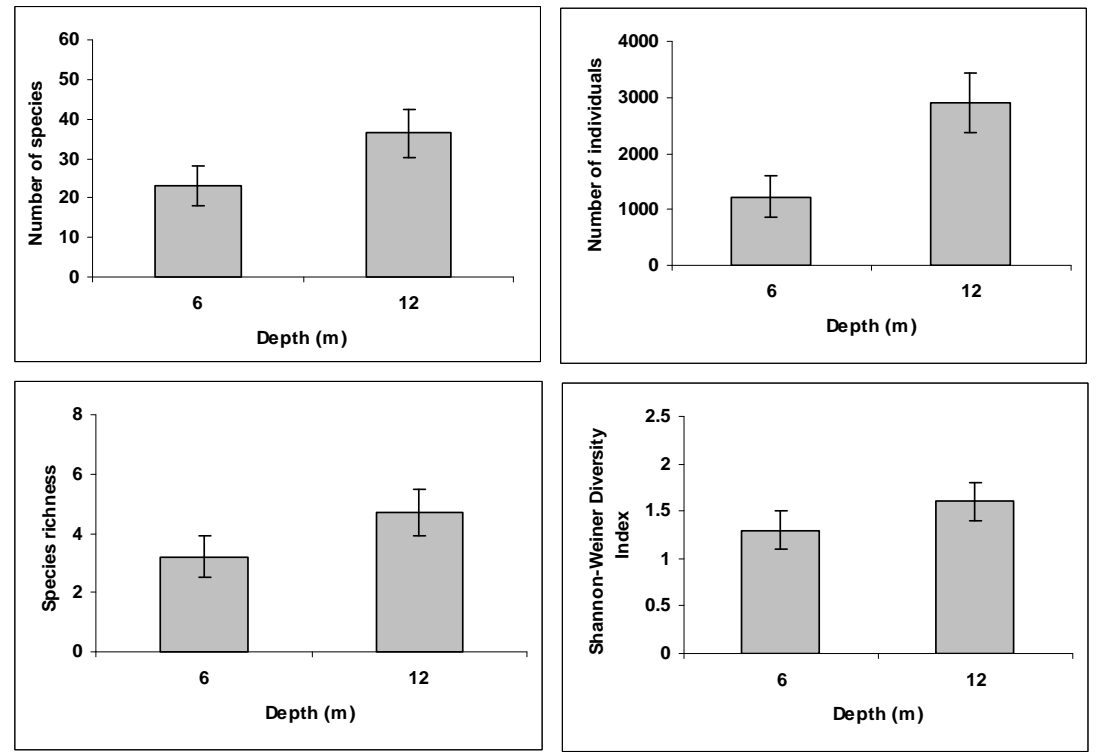

Figure 3. Average number of species, average number of individuals, average species richness and average Shannon Wiener Diversity Index at $6 \mathrm{~m}$ and 12 depths in the studies sea grass sites.

cally important fish species such as $L$. borbonicus, $L$. variegatus, D. macarellus and S. rivulatus. Those species are known to live in such habitat [26]. The fish observed during the study were mostly juvenile which support the assumption that seagrass beds can serve as a nursery area for the successful development of the juvenile stages [1]. Seagrass beds play significant role in harboring juveniles of various commercial fish (e.g. Lethrinids, Siganids and
Mullids) and many of these critically important to local fisheries. Similar results were also reported in the Wakatobi Marine National Park, Indonesia by [27]. Availability of food, shelter and protection from predators within the seagrass lattice contribute to the nursery functions of these habitats. Hence, understand well the contribution of seagrass beds to coastal fisheries in terms of fish distribution, species composition and spawning seasons. This 
site can support the fishery stock along the Jordanian coast. In light of future developments in the area and the consequences of the constructing various sea based facilities including the Red Sea canal project. This site should be taken into consideration as high valuable habitat for the fish community in the Gulf of Aqaba including the commercial fish species and its consequences on the fishermen community in the city of Aqaba. Teixeirichthys jordani, Jordan's damselfish is of considerable importance in term of conservation. This species is reported only at the northern site and not present elsewhere along the Jordanian coast [12].

The coral reef fishes along the Jordanian coast are dominated by Pomacentridae, followed by Anthininae (subfamily of Serranidae) and Labridae [28]. Visual censuses of fish assemblages in this study revealed the dominance of Lethrinidae, followed by Pomacentridae, Serranidae, Siganidae and Labridae.

The number of species was significantly higher in sea grass sites that has more coral cover than in seagrass site with lower coral cover, which indicate close relationship between the two habitats and that they might exchange fish species among each others [29] with low coral cover. This could be attributed to a higher abundance of shelter and food resources present in coral reef habitats. A review of literature describing fish habitat correlation from various regions of the world presents a convincing positive relationship between structural complexity and reef fish diversity in the Caribbean [30,31] and in the Great Barrier Reef [32]. Reef associated fishes, due to their behavior are extremely affected by the characteristics of the reef habitat. Several studies have shown that the species diversity, abundance and biomass of the fish community are positively correlated with the structural complexity of the substrate and the live benthic cover, which influence the fish community structure via feeding inter-action [33]. In this study, there was an evidence of the habitat characteristics effect on the number of species and species richness in the various types of habitat along the Jordanian coast of the Gulf of Aqaba.

The number of individuals in the HA site was higher than the other two sites. This is probably due to the closeness of the northern site to the site of the fish cages in the neighboring Israeli border, where plenty of nutrient support the food chain in the area [34].

The $12 \mathrm{~m}$ deep transects in the seagrass habitat had the highest fish abundance compared with the shallow depths at $6 \mathrm{~m}$ within the same habitat. Similar results were found by [35] when he examined differences in fish assemblages in deep and shallow margins of the seagrass Posidonia oceanica beds and reported significantly more fishes in deep seagrass than shallow. [36] found high correlation of the fish community with depth in the northern tip of the Red Sea. Many planktivorous fishes are abundant at this depth such as, $P$. squampinnis, $P$. octotaenia, C. Pelloura, D. macarellus, and C. rubriventralis probably in relation with a high abundance of plankton at this depth. Depth influences the composition and distribution of fish communities within tropical reefs [37,38]. At $12 \mathrm{~m}$ depth, the most abundant species in seagrass habitat were L. borbonius, L. variegatus, a typical generalist that feeds on a variable diet on crustaceans, echinoids, mollusks as well as small fishes [26]. A group of 11 species of herbivorous grazing fish belonging to the families Acanthuridae, Scaridae and Siganidae was studies in the area. Some of those were more abundant in $12 \mathrm{~m}$ deep such as: $S$. rivulatus and $S$. luridus. The $T$. jordani is restricted to the Northern Beach site. Although, C. pelloura was mentioned to be present at depths greater than $30 \mathrm{~m}$ [39], in this study it was found at $12 \mathrm{~m}$ depths. This research stresses the major role of the habitat and depth in shaping the community structure.

\section{ACKNOWLEDGEMENTS}

We thank the technical and administrative staff of the Marine Science Station, particularly Mr. O. Al-Momany for assistance with field work. Special tribute to the memory of Mr. Y. Jamal who passed away for his field and lab assistance. This work was supported by the Marine Science Station and Aqaba Special Economic Zone Authority, Aqaba/ Jordan.

\section{REFERENCES}

[1] Jackson, E.L., Rowden, A.A., Attrill, M.J., Bossey, S.J. and Jones, M.B. (2001) The importance of seagrass beds as a habitat for fishery species. Oceanography and $\mathrm{Ma}$ rine Biology, 39, 269-303.

[2] Heck, K.L., Hays, G. and Orth, R.J. (2003) Critical evaluation of the nursery role hypothesis for seagrass meadows. Marine Ecology Progress Series, 253, 123-136. doi:10.3354/meps 253123

[3] Edwards, A.J. and Head, S. (1987) Key environments red sea. 1st Edition, Pergamon, Oxfrod, p. 441.

[4] Den Hartog, C. (1977) Seagrasses and seagrass ecosystems, an appraisal of the research approach. Aquatic Botany, 7, 105-117.

doi:10.1016/0304-3770(79)90015-9

[5] Fishelson, L. (1971) Ecology and distribution of the benthic fauna in the shallow waters of the Red Sea. Marine Biology, 10, 113-133. doi:10.1007/BF00354828

[6] Lipkin, Y. (1979) Quantitative aspects of seagrass communities, particularly those dominated by. Halophila stipulacea, in Sinai (Northern Red Sea). Aquatic.

[7] Hulings, N.C. (1979) The ecology, biometry and biomass of the seagrass Halophila stipulacea along the Jordanina coast of the Gulf of Aqaba. Botanica Marina, 22, 425430. doi:10.1515/botm.1979.22.7.425 
[8] Beer, S. and Waisel, Y. (1982) Effects of light and pressure on photosynthesis in two seagrasses. Aquatic Botany, 13, 331-337. doi:10.1016/0304-3770(82)90068-7

[9] Wahbeh, M.I. (1980) Studies on the ecology and productivity of the seagrass Halophila stipulacea and some associated organisms in the Gulf of Aqaba (Jordan). Ph.D Thesis, University of York, England.

[10] Whahbeh, M.I. (1982) Distribution, biomass, biometry and asome associated fauna of seagrass community in the Jordan Gulf of Aqaba. Proceeding of the 4th International Coral Reef Symposium, Manila, 453-459.

[11] Al-Rousan, S., Rasheed, M., Khalaf, M.A. and Badran, M. (2005) Bottom habitat and biological characteristics of the Jordanian northern Gulf of Aqaba. Chemistry \& Ecology, 21, 227-239. doi:10.1080/02757540500211277

[12] Khalaf, M.A. (2004) Fish fauna along the Jordanian Coast-Gulf of Aqaba. Journal of Faculty of Marine Science, 15, 23-50.

[13] Goren, M and Dor, M. (1994) An update checklist of the fishes of the Red Sea. CLOFERS II, Jerusalem.

[14] Khalaf, M.A. (2005) Five additional records of fishes from the Gulf of Aqaba, including Mola mola (Forsskäl, 1775), new for the Red Sea. Zoology in the Middle East, 34, 45-42.

[15] Genin, A, Jaffe, J.S., Reef, R., Richter, C. and Frank, P.J.S. (2005) Swimming against the flow: Amechanism of zooplankton aggregation. Science, 308, 860-862. doi:10.1126/science.1107834

[16] Al-Rousan, S.A., Al-Shloul, R.N., Al-Horani, F.A. and Abu-Hilal, A.H. (2007) Heavy metal contents in growth bands of Porites corals: Record of anthropogenic and human developments from the Jordanian Gulf of Aqaba. Marine Pollution Bulletin, 24, 1912-1922. doi:10.1016/j.marpolbul.2007.08.014

[17] UNEP/IUCN (1988) Coral reefs of the world. UNEP Regional Sea Directories and Bibliographies. IUCN, Gland, Switzerland and Cambridge, UK/UNEP, Nairobi, Kenya.

[18] Berman, T., Paldor, N. and Brenner, S. (2000) Simulation of wind-driven circulation in the Gulf of Elat (Aqaba). Journal of Marine System, 26, 349-365. doi:10.1016/S0924-7963(00)00045-2

[19] Manasrah, R., Badran, M.H., Lass, U. and Fennel, W.G. (2004) Circulation and winter deep-water formation in the northern Red Sea. Oceanologia, 46, 5-23.

[20] English, C., Wilkinson, C. and Baker, V. (Eds.) (1994) Survey manual for tropical marine resources. Australian Institute of Marine Science, Townsville.

[21] Ohlhorst, S.L. Liddell, W.D., Taylor, R.J. and Taylor, J.M. (1988) Evaluation of reef census techniques. Proceedings of 6th International Coral Reef Symposium, Townsville, 2, 319-324.

[22] Rogers, C.S., Garrison, G., Grober, R., Hillis, Z.M. and Franke, M.A. (1994) Coral reef monitoring manual for the Caribbean and western Atlantic National Park Service. Virgin Islands National Park.

[23] Sokal, R.R. and Rohlf, F.J. (1981) Biometry. W. H.
Freeman and Company, San Francisco, California.

[24] Ludwig, J.A. and Reynolds, J.F (1988) Statistical ecology. John Wiley and Sons, New York.

[25] Peet, R.K. (1974) The measurement of species diversity. Annual Review of Ecological and Systematics, 5, 285-307. doi:10.1146/annurev.es.05.110174.001441

[26] Khalaf, M.A. and Disi, A.M. (1997) Fishes of the Gulf of Aqaba. Marine Science Station.

[27] Unsworth, R.K.F., Garrard, S.L., De Leon, P.S., Cullen, L.C., Smith, D.J., Sloman, K.A. and Bell, J.J. (2009) Structuring of Indo-Pacific fish assemblages along the mangrove-seagrass continuum. Aquatic Biology, 5, 85-95. doi:10.3354/ab00139

[28] Khalaf, M.A. and Kochzius, M. (2002) Community structure and biogeography of shore fishes in the Gulf of Aqaba, Red Sea. Helgoland Marine Research, 55, 252284. doi:10.1007/s10152-001-0090-y

[29] Kochzius, M. (1999) Interrelation of ichthyofauna from a seagrass meadow and coral reef in the Philippines. In: Sere, B. and Sire, J.-Y., Eds., Proceeding of the 5th IndoPacific fish conference, Noumea, 3-8 November 1997, Societe Francaise d'Ichtjyologie and Institut de Recherché Pou Le Development, Paris, 517-535.

[30] Risk, M.J. (1972) Fish diversity on a coral reef in the Virgin Island. Atoll Research Bulletin, 153, 1-6.

[31] Luckhurt, B.E. and Luckurt, K. (1978) Analysis of the influence of the substrate variables on coral reef fish communities. Marine Biology, 49, 317-323. doi:10.1007/BF00455026

[32] McCormick, M.I. (1994) Comparison of field models for measuring surface topography and their association with a tropical reef fish community. Marine Ecology Progress Series, 112, 87-96. doi:10.3354/meps 112087

[33] Pereira, M.A.M. (2000) A review on the Ecology, exploitation and conservation of reef fish resources in Mozambique. 2nd National Conference on Coastal Zones Research, Maputo, 1-9.

[34] Al-Zibdah, M., Oqaily, F., Al-Najjar, T. and Manasrah, R. (2008) Neighboring cage fish farming affecting water and seabed quality of the Jordanian Northern Gulf of Aqaba. Red Sea Ocean Science Journal, 43, 9-16.

[35] Bell, J.D. and Pollard, D.A. (1989) Ecology of fish assemblages and fisheries associated with seagrasses. In: Larkum, A.W.D., McComb, A.J. and Shepherd, S.A., Eds., Biology of Seagrasses. A Treatise on the Biology of Seagrasses with Special Reference to the Australian Region. Elsevier, New York, 565-597.

[36] Brokovich, E., Baranes, A. and Goren, M. (2006) Habitat structure determines coral reef fish assemblages at the northern tip of the Red Sea. Ecological Indicators, 6, 494-507. doi:10.1016/j.ecolind.2005.07.002

[37] Goldman, B. and Talbot, F.I. (1976) Aspects of ecology of the coral reef fishes. In: Jones, O.A. and Endean, R., Eds., Biology and Geology of Coral Reefs, Academic Press, New York, 125-154.

[38] Williams, D.M. (1991) Patterns and processes in the distribution of coral reef fishes. In: Sale, P.F., Ed., The 
Ecology of Coral Reef Fishes, Academic Press, San Diego, 437-474.
[39] Randall, J.E. (1983) Red Sea reef fishes. Immel Publishing, London. 